\title{
Concurrent validity of handgrip strength between the jamar and bulb dynamometers in women with rheumatoid arthitis
}

\author{
Validade concorrente da força de preensão palmar entre os \\ dinamômetros Jamar e de bulbo em mulheres com artrite reumatoide
}

Validez concurrente de la fuerza de prensión palmar entre los
dinamómetros Jamar y de bulbo en mujeres con artritis reumatoide

Lygia Paccini Lustosa ${ }^{\circledR}$, Karla Gonçalves Diogo ${ }^{\circledR}$, Giane Amorim Ribeiro-Samora ${ }^{\circledR}$, Adriana Maria Kakehasi $(\mathbb{D}$, Mariana Asmar Alencar $(\mathbb{1} *$ *

Universidade Federal de Minas Gerais (UFMG), Belo Horizonte, MG, Brazil

Abstract

\begin{abstract}
Introduction: Rheumatoid arthritis (RA) is a progressive disease that causes deformation and constant joint damage. Handgrip strength (HGS) has been used by several health professionals in clinical practice as a mechanism for assessing muscle strength and overall performance. Objective: To perform the concordance analysis of handgrip strength measurements using a pneumatic dynamometer (Bulb) and a hydraulic dynamometer (Jamar) in women with rheumatoid arthritis. Method: The HGS measurements by the two dynamometers followed the norms of the American Society of Hand Therapists. The concordance between measurements was performed by the Bland-Altman method. Significance level was $5 \%$. Results: In total, 41 women ( $60.63 \pm 8.35$ years) participated in the study. Analysis showed that the measures between the two dynamometers were not concordant (bias $=9.04, \mathrm{p}<0.01$ ), there was a linear relationship between
\end{abstract}

* LPL: PhD, e-mail: lygiapl@ufmg.br KGD: MS, e-mail: fisio.karlagoncalves@gmail.com GARS: PhD, e-mail: gribeirosamora@gmail.com AMK: PhD, e-mail: amkakehasi@gmail.com MAA: PhD, e-mail: masmaralencar@yahoo.com.br 
the difference of the measures and the mean ( $\mathrm{r}=0.73, \mathrm{p}<0.01)$, and the limits of agreement were very extensive (-2.74 to 20.81). Conclusion: Assuming that the rheumatoid arthritis compromises the hands, with a consequent decrease in HGS, further exploration of the subject is suggested in future studies to define the best measure for clinical practice at the different levels of health care. However, since there are many different dynamometers, we suggest to better explore the agreement between the measurements obtained by them in populations under different conditions.

Keywords: Arthritis, Rheumatoid. Muscle Strength. Muscle Strength Dynamometer.

\section{Resumo}

Introdução: Artrite reumatóide (AR) é uma doença progressiva que causa deformação e comprometimento articular. A força de preensão palmar (FPP) tem sido usada por vários profissionais de saúde, na prática clínica, para avaliar força muscular e desempenho. Objetivo: Analisar a concordância das medidas de força de preensão palmar usando o dinamômetro pneumático (Bulbo) e hidráulico (Jamar) em mulheres com artrite reumatoide. Método: As medidas de FPP pelos dois dinamômetros seguiram as normas da American Society of Hand Therapists. A concordância entre as medidas foi por meio do método de Bland-Altman. Nível de significância de 5\%. Resultados: Participaram 41 mulheres $(60,63 \pm 8,35$ anos). A análise entre os dois dinamômetros demonstrou não haver concordância (bias $=9,04, p<0,01$ ), com uma relação linear entre a diferença das medidas e a média $(r=0,73, p<0,01)$ e, os limites de concordância foram muito extensos $(-2,74$ to 20,81). Conclusão: Como a artrite reumatoide compromete as mãos com consequente diminuição da FPP, é importante explorar melhor este tema para definir a melhor medida para a prática clínica nos diferentes níveis de atenção à saúde. No entanto, devido ao grande número de tipo de dinamômetros, sugere-se novos estudos sobre a concordância destas medidas em populações de diferentes condições.

Palavras-chave: Artrite Reumatoide. Força Muscular. Dinamômetro de Força Muscular.

\section{Resumen}

Introducción: La artritis reumatoide (AR) es una enfermedad progresiva que causa deformación y compromiso articular. La fuerza de prensión palmar (FPP) ha sido utilizada por varios profesionales de la salud, en la práctica clínica, para evaluar la fuerza muscular y el rendimiento. Objetivo: Analizar la concordancia de las medidas de fuerza de prensión palmar usando el dinamómetro neumático (Bulbo) e hidráulico (Jamar) en mujeres con artritis reumatoide. Método: Las medidas de FPP por los dos dinamómetros siguieron las normas de la American Society of Hand Therapists. La concordancia entre las medidas fue mediante el método de Bland-Altman. Nivel de significancia del 5\%. Resultados: Participaron 41 mujeres $(60,63 \pm 8,35$ años). El análisis entre los dos dinamómetros demostró no haber concordancia (bias $=9,04, p<0,01$ ), con una relación lineal entre la diferencia de las medidas y la media ( $r=0,73, p<0,01)$, los límites de concordancia fueron muy extensos (-2,74 a 20,81). Conclusión: Como la artritis reumatoide compromete las manos con consecuente disminución de la FPP, es importante explorar mejor este tema para definir la mejor medida para la práctica clínica en los diferentes niveles de atención a la salud. Sin embargo, debido al gran número de dinamómetros, se sugiere nuevos estudios sobre la concordancia de estas medidas en poblaciones de diferentes condiciones.

Palabras clave: Artritis Reumatoide. Fuerza Muscular. Dinamómetro de Fuerza Muscular. 


\section{Introduction}

Rheumatoid arthritis (RA) is a progressive disease that causes deformation and constant joint damage, leading to disability $[1,2]$. The limitations caused by this condition impact the quality of life of people affected and of the health system, the costs generated by treatment and disability $[3,4]$. The pathophysiology of RA is characterized by synovial membrane changes with thickening, inflammation and changes in blood vessels [5]. The joint infiltration and activation of proinflammatory cytokines that act with chondrocytes and osteoclasts, causing a recurrent destruction of the affected joint $[5,6]$. This joint impairment results in individual's reduced functional capacity to perform and elaborate tasks [2, 3, 7-9]. Reports of loss of hand and wrist function account for up to $70 \%$ of complaints $[3,10]$.

Handgrip strength (HGS) has been used by several health professionals in clinical practice as a mechanism for assessing muscle strength and overall performance, since the hands are used to perform various activities of daily living [11]. HGS is a relevant measure to estimate overall muscle impairment, specially in diseases that affect skeletal muscle tissue. This measure is also a predictive of several health outcomes with aging. HGS is an important measure in the context of rheumatic diseases such as rheumatoid arthritis, since it can inform about the functionality of the hands of people affected, in addition to predict the health outcomes [11-13]. It is an easy, low-cost measure with great applicability at all levels of health care. Studies have reported no difference in strength in individuals that have dominance in the left hand, suggesting that the hands have similar strength [14-17].

The commonly used instrument for assessing HGS is the manual dynamometer. Many models were created and categorized into four classes: hydraulic, pneumatic, mechanical and electronic dynamometers $[11,16,18]$. Manual dynamometry is an efficient test for the evaluation and monitoring of therapeutic progress, training and scientific study. Manual dynamometers have the advantage of being portable and easy to handle $[13,14,18]$, and can be used in primary care, clinics and hospitals. The hydraulic dynamometer has been considered as the gold standard for handgrip measure [18]. However, since there are many different dynamometers, we think it is important to identify the agreement between the measures obtained by each one and if there is a dynamometer that could better evaluate a specific population $[16,17]$. The pneumatic dynamometer is small, light, cheap, easy to use and made of a soft material, thus being a good alternative to evaluate individuals with rheumatoid arthritis $[16,17]$. This is based on the possibility that its adjustment to the hand is more adequate due to deformities caused by rheumatoid arthritis. Evaluating the concurrent validity of pneumatic dynamometer with the gold standard may increase the possibility of this instruments being used by professionals.

Thus, our study sought to perform the agreement analysis of handgrip strength measurements using a pneumatic and a hydraulic dynamometer in women diagnosed with rheumatoid arthritis.

\section{Methods}

This is a cross-section study, approved by the Institutional Ethics and Research Board with a sample of convenience. Our study was conducted in the university outpatient clinic of rheumatic diseases. All the participants were informed of the benefits and risks of the investigation before signing the informed consent form.

Thus, women aged 45 years and over, without distinction of race and/ or social class, were invited to participate in our study. They should have been diagnosed more than two years prior to the study, and participate in the university's outpatient control program. They should not be in the active phase of the disease. Exclusion criteria were: presence of pain that hinders the participation in the tests, neurological diseases and/or sequelae, fractures of the upper and lower limbs less than one year prior to the study, and women that did not reach the cutoff point according to schooling in the Mental State Mini Exam [19].

\section{Procedures}

All the procedures were performed by a previously trained researcher, starting with an interview to characterize the clinic and sociodemographic profile of the participants. The researcher was trained during the month prior to the start of data collection and presented good intra-rater reliability (ICC $=0.98$ ). Subsequently, the HGS measurements were performed using the Jamar manual dynamometer (model Sh5001, Saehan Corporation) with the handle 
in the $2^{\text {nd }}$ position and the bulb dynamometer (New Saehan Squeeze Dynamometer - SH 5008). In our study, the use of dynamometers was randomized.

The Jamar dynamometer has been recommended as a gold standard by the American Society of Hand Therapists (ASHT) $[13,14]$. This is a hydraulic system equipment composed of parallel-arranged handles: one fixed and one movable handle that can be adjusted in five different positions [12-14, 17]. It is considered an inter-rater reliability and testretest equipment $[17,20]$. It is accurate for the investigation of handgrip strength and has a protocol also recommended by ASHT, a fact that allows data reproducibility $[13,14]$. The bulb dynamometer is an example of the pneumatic dynamometer category. This dynamometer has a silicone bag, is anatomically shaped, lightweighted and easy to handle. Unlike the hydraulic dynamometer, the maximum force exerted by the participant is not isometric but has a dynamic start in pressure $[17,21]$.

To perform the test with the two dynamometers, the participant was seated in a chair without arm support, with the back supported on the backrest, knees flexed at $90^{\circ}$, feet supported, shoulder adducted, elbow flexed at $90^{\circ}$, forearm in a neutral position, wrist position ranging from 0 to $30^{\circ}$, respecting the deformities of the hand of the participants $[11,13]$. The participant received guidance on the test and performed the highest HGS after the "Go" command, maintaining the contraction maximum isometric for six seconds. Throughout the test, there was verbal stimulation through the words "force, force..." and constant palms [17]. Three measures were performed in the dominant hand with a one-minute interval between each measurement $[17,22]$.

\section{Statistical analysis}

The descriptive analysis of the sample is shown on average, percentage and standard deviation. The mean of the three measures of the dominant hand was used for the concordance analysis, using the Bland-Altman method. This method consists of a statistical and graphical procedure used to evaluate the agreement between two methods by estimating the bias (difference between the measurements obtained by the two methods), the mean and the standard deviation (SD) of these differences, besides the upper limit of agreement (ULA) and lower limit of agreement (LLA), obtained by the equation: bias \pm 1.96 (standard deviation). We adopted a $5 \%$ significance level.

\section{Results}

Forty-one women participated in our study. The mean age was $60.63( \pm 8.35)$ years, with a minimum of 47 years and a maximum of 82 years. Most participants were married, mixed race, with education between 1 st and 4 th grade and retired. The socio-demographic characteristics are shown in Table 1.

Table 1-Socio-demographic characteristics of study participants

\begin{tabular}{|c|c|}
\hline Variable & $(n=41)$ \\
\hline Age, years, mean (SD) & $60.6(8.4)$ \\
\hline \multicolumn{2}{|l|}{ Schooling } \\
\hline Up to 4 years, n (\%) & $18.0(43.9)$ \\
\hline From 5 to 8 years, $n(\%)$ & $10.0(24.4)$ \\
\hline Above 9 years, $n(\%)$ & $13.0(31.7)$ \\
\hline \multicolumn{2}{|l|}{ Marital status } \\
\hline Married, n (\%) & $24.0(58.5)$ \\
\hline Single, $\mathrm{n}(\%)$ & $8.0(19.5)$ \\
\hline Divorce, n (\%) & $4.0(9.8)$ \\
\hline Widow, n (\%) & $5.0(12.2)$ \\
\hline \multicolumn{2}{|l|}{ Race } \\
\hline White, n (\%) & $11.0(26.8)$ \\
\hline Mixed, n (\%) & $21.0(51.2)$ \\
\hline Others, $n(\%)$ & $9.0(22.0)$ \\
\hline Income (in minimum wages), mean (SD) & $1.3(0.7)$ \\
\hline Smoker, n (\%) & $7.0(17.1)$ \\
\hline \multicolumn{2}{|l|}{ Lives with } \\
\hline Alone, n (\%) & $4.0(9.8)$ \\
\hline With husband, n (\%) & $19.0(46.3)$ \\
\hline With children, $\mathrm{n}(\%)$ & $18.0(43.9)$ \\
\hline Diagnostic time (in years), mean (SD) & $14.2(10.4)$ \\
\hline Medication, mean (SD) & $6.8(2.6)$ \\
\hline
\end{tabular}

Note: SD: standard deviations.

The mean of the HGS measurements performed on the two dynamometers was different, as shown in Figure 1. 


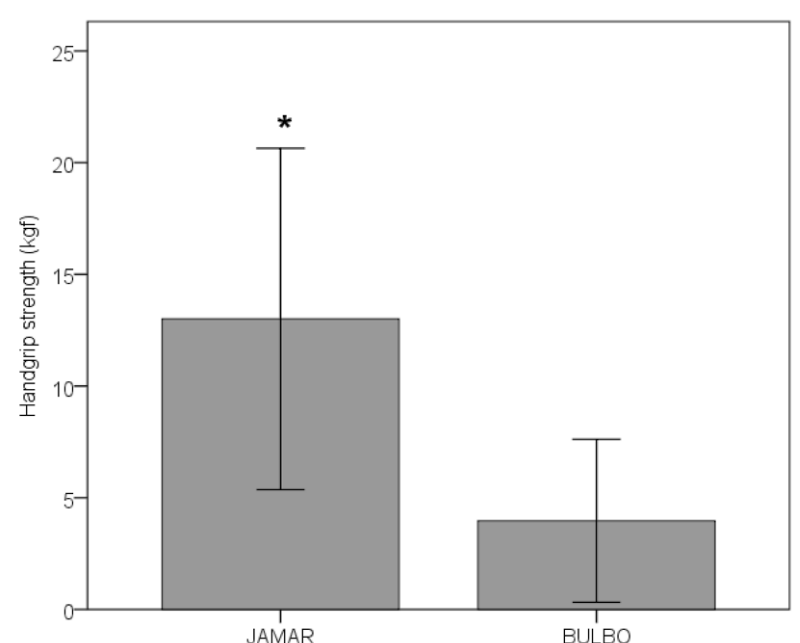

Note: ${ }^{*}: p<0.01$ for the comparison between the Jamar and Bulb dynamometer (student-dependent T-test).

Figure 1 - Mean and standard deviation of handgrip strength measurements for Jamar and Bulb dynamometers.

The Bland-Altman analysis showed nonagreement between the HGS measurements of the Jamar and Bulb dynamometers, since the bias was statistically different from zero (bias $=9.04, \mathrm{p}<0.01$ ). In addition, there was a linear relationship between the difference of means $(r=0.73, p<0.01)$, which indicates that the error between the two measures increases with the increase in HGS. Moreover, the limits of agreement were very extensive $(-2.74$ to 20.81), as shown in Figure 2.

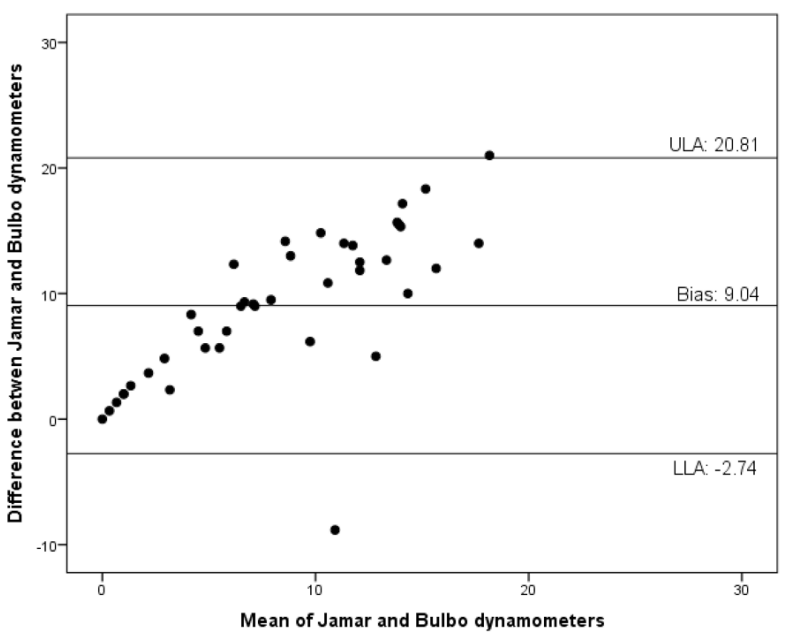

Note: ULA: upper limit of agreement; LLA: lower limit of agreement.

Figure 2 - Graphical analysis of the agreement between the measurements on the Jamar and Bulb dynamometers according to Bland-Altman.

\section{Discussion}

Our study sought to identify the agreement between the values of HGS performed with two different dynamometers. The results showed nonagreement between the measures, with non-zero error and presence of a linear relationship between the difference and the mean of the measurements, i.e., the greater the HGS the greater the possibility of a variable error of the measurements between the dynamometers.

The dynamometers chosen for our study showed differences in both design and conduction. The Jamar dynamometer is hydraulic, with closed system, capable of recording the voltage from the isometric contraction $[13,23]$. When gripping, the loops deform and approach in a non-perceptible manner transmitting the tension to the manometer in a manner proportional to the force applied, characterizing a handgrip on a hook. On the other hand, the strength of the handgrip measured by the bulb dynamometer has a cylindrical shape, according to the shape of the bulb [23]. Moreover, the pneumatic dynamometer used here did not have the option of replacing the bulb to adapt the equipment to the participant $[16,17]$. Our hypothesis was that the bulb dynamometer could be more comfortable for the participants, considering possible hand deformities [11]. However, the results showed that both silicone bag (bulb) or the rods (Jamar) may have interfered with the applied force and should be considered in clinical practice.

In our study, the deformities of the participants' hands were not measured and controlled, only the absence of pain. The hand is a sensory organ that enables an efficient relation with the environment in which the individual is inserted [23, 24]. For the handgrip, the integrity of the hand is a condition to be observed, since this movement involves the thumb that participates with movement phalangeal metacarpal joints in extension and flexion movements, adduction and ulnar deviation, in addition to the action of intrinsic and extrinsic nerves and muscles of the hand [23-25]. In the intention of transmitting force to another object, as in the dynamometer test, the deformities present in the hands of people with RA could alter this ability to transmit and adapt to 
the devices, influencing handgrip strength measures $[7,16,24-29]$. Thus, even by standardizing the test position, the existence of these joint limitations may have interfered in measures by the mechanical advantage of the muscles involved in handgrip strength [30]. This would be a possible limitation of the study, since no specific measures were performed to determine hand deformities, which should be studied in the future.

In this context, Innes [16] and Shiratori et al. [17] affirmed that pneumatic dynamometers would be better suited for people with pain or deformity in the hands [29], which cannot be confirmed with the results of our study. Besides, Beaudart et al. [21] evaluated different instruments, aiming at the diagnosis of sarcopenia [29], but compared handgrip strength measurements between hydraulic and pneumatic dynamometers. These authors also did not identify agreement between the measurements of both instruments, pointing out that the pneumatic dynamometer diagnosed twice as many patients with sarcopenia [21]. Likewise, our study showed nonagreement, in this case for RA.

Based on the results of our study, it cannot be affirmed that the measures of the two instruments are clinically comparable. However, further studies should better explore this condition, including time of diagnosis, type of deformities and age-related excess, which could contribute to a detailed and more judicious profile of HGS in RA women [29].

\section{Conclusion}

Our study demonstrated non-agreement between handgrip strength measurements of Jamar and Bulb dynamometers in women with rheumatoid arthritis. Assuming that the rheumatoid arthritis compromises the hands, with a consequent decrease in HGS, further exploration of the subject is suggested in future studies to define the best measure for clinical practice at the different levels of health care. However, since there are many different dynamometers, we suggest to better explore the agreement between the measurements obtained by them in populations under different conditions.

\section{References}

1. Lee DM, Weinblatt ME. Rheumatoid arthritis. Lancet. 2001;358(9285):903-11.
2. Mota LMH, Cruz BA, Brenol CV, Pereira IA, Fronza LSR, Bertolo MB et al. 2011 consensus of the Brazilian Society of Rheumatology for diagnosis and early assessment of rheumatoid arthritis. Rev Bras Reumatol. 2011;51(3):199-219.

3. Palamar D, Er G, Terlemez R, Ustun I, Can G, Saridogan M. Disease activity, handgrip strengths, and hand dexterity in patients with rheumatoid arthritis. Clin Rheumatol. 2017;36(10):2201-8.

4. Erol K, Gok K, Cengiz C, Ozgocmen S. Hand functions in systemic sclerosis and rheumatoid arthritis and influence on clinical variables. Int J Rheum Dis. 2018;21(1):249-52.

5. Faleiro LR, Araújo LHR, Varavallo MA. A terapia antiTNF- $\alpha$ na artrite reumatóide. Semina Cienc Biol Saude. 2011;32(1):77-94.

6. Firestein GS. The disease formerly known as rheumatoid arthritis. Arthritis Res Ther. 2014;16(3):114.

7. Aletaha D, Neogi T, Silman AJ, Funovits J, Felson DT, Bingham CO 3rd et al. 2010 Rheumatoid arthritis classification criteria: an American College of Rheumatology/ European League against Rheumatism collaborative initiative. Arthritis Rheum. 2010;62(9):2569-81.

8. Farias N, Buchalla CM. A classificação internacional de funcionalidade, incapacidade e saúde da organização mundial da saúde: conceitos, usos e perspectivas. Rev Bras Epidemiol. 2005;8(2):187-93.

9. Norton S, Sacker A, Dixey J, Done J, Williams P, Young A. Trajectories of functional limitation in early rheumatoid arthritis and their association with mortality. Rheumatology. 2013;52(11):2016-24.

10. Williams MA, Williamson EM, Heine PJ, Nichols V, Glover MJ, Dritsaki M et al. Strengthening and stretching for Rheumatoid Arthritis of the Hand (SARAH): a randomized controlled trial and economic evaluation. Health Technol Assess. 2015;19(19):1-222.

11. Higgins SC, Adams J, Hughes R. Measuring handgrip strength in rheumatoid arthritis. Rheumatol Int. 2018;38(5):707-14. 
12. Amaral JF, Mancini M, Novo JM Jr. Comparison of three hand dynamometers in relation to the accuracy and precision of the measurements. Rev Bras Fisioter. 2012;16(3):216-24.

13. Figueiredo IM, Sampaio RF, Mancini MC, Silva FCM, Souza MAP. Test of grip strength using the Jamar dynamometer. Acta Fisiatr. 2007;14(2):104-10.

14. Dias JA, Ovando AC, Külkamp W, Borges NG Jr. Força de preensão palmar: métodos de avaliação e fatores que influenciam a medida. Rev Bras Cineantropom Desempenho Hum. 2010;12(3):209-16.

15. Geraldes AR, Oliveira ARM, Albuquerque RB, Carvalho JM, Farinatti PTV. A força de preensão manual é boa preditora do desempenho funcional de idosos frágeis: um estudo correlacional múltiplo. Rev Bras Med Esporte. 2008;14(1):12-6.

16. Innes E. Handgrip strength testing: a review of the literature. Aust Occup Ther J. 1999;46(3):120-40.

17. Shiratori AP, Iop RR, Borges NG Jr, Domenech SC, Gevaerd MS. Evaluation protocols of handgrip strength in individuals with rheumatoid arthritis: a systematic review. Rev Bras Reumatol. 2014;54(2):140-7.

18. Hogrel JY. Grip strength measured by high precision dynamometry in healthy subjects from 5 to 80 years. BMC Musculoskelet Disord. 2015;16:139.

19. Bertolucci PHF, Brucki SMD, Campacci SR, Juliano Y. O Mini-Exame do Estado Mental em uma população geral: impacto da escolaridade. Arq NeuroPsiquiatr. 1994;52(1):1-7.

20. Bohannon RW. Test-retest reliability of measurements of handgrip strength obtained by dynamometry from older adults: a systematic review of research in the PubMed database. J Frailty Aging. 2017;6(2):83-7.

21. Beaudart C, Reginster JY, Slomian J, Buckinx F, Dardenne N, Quabron A et al. Estimation of sarcopenia prevalence using various assessment tools. Exp Gerontol. 2015;61:31-7.

22. Desrosiers J, Bravo G, Hérbert R, Dutil E. Normative data for grip strength of elderly men and women. Am J Occup Ther. 1995;49(7):637-44.
23. Guerra RS, Amaral TF, Sousa AS, Fonseca I, Pichel F, Restivo MT. Comparison with Jamar and bodygrip dynamometers for handgrip strength measurement.J Strength Cond Res. 2017;31(7):1931-40.

24. Sangole AP, Levin MF. Arches of the hand in reach to grasp. J Biomech. 2008;41(4):829-37.

25. Senna ER, Barros ALP, Silva EO, Costa IF, Pereira LVB, Ciconelli RM et al. Prevalence of rheumatic diseases in Brazil: a study using the COPCORD approach. J Rheumatol. 2004;31(3):594-7.

26. Bombardier C, Barbieri M, Parthan A, Zack DJ, Walker $\mathrm{V}$, Macarios $\mathrm{D}$ et al. The relationship between joint damage and functional disability in rheumatoid arthritis: a systematic review. Ann Rheum Dis. 2012;71(6):836-44.

27. Zaleski AL, Taylor BA, Panza GA, Wu Y, Pescatello LS, Thompson PD et al. Coming of age: considerations in the prescription of exercise for older adults. Methodist Debakey Cardiovasc J. 2016;12(2):98-104.

28. Rydholm M, BookC, Wikström I,Jacobsson L, Turesson C. Course of grip force impairment in patients with early rheumatoid arthritis over the first five years after diagnosis. Arthritis Care Res. 2018;70(4):491-8.

29. Beenakker KG, Ling CH, Meskers CG, de Craen AJ, Stijnen J, Westendorp RG et al. Patterns of muscle strength loss with age in the general population and patients with a chronic inflammatory state. Ageing Res Rev. 2010;9(4):431-6.

30. Silva GS, Lourenço MA, Assis MR. Hand strength in patients with RA correlates strongly with function but not with activity of disease. Adv Rheumatol. 2018;58:20.

Received in 05/27/2019

Recebido em 27/05/2019

Recibido en 27/05/2019

Approved in 10/21/2019

Aprovado em 21/10/2019

Aprobado en 21/10/2019 